\title{
Article \\ Biotic and Abiotic Biostimulation for the Reduction of Hexavalent Chromium in Contaminated Aquifers
}

\author{
Andriani Galani, Daniel Mamais *, Constantinos Noutsopoulos (D), Petra Anastopoulou and Alexia Varouxaki
}

check for

updates

Citation: Galani, A.; Mamais, D.;

Noutsopoulos, C.; Anastopoulou, P.; Varouxaki, A. Biotic and Abiotic Biostimulation for the Reduction of Hexavalent Chromium in Contaminated Aquifers. Water 2022, 14, 89. https://doi.org/10.3390/ w14010089

\section{Academic Editor:}

Domenico Cicchella

Received: 26 October 2021

Accepted: 30 December 2021

Published: 4 January 2022

Publisher's Note: MDPI stays neutral with regard to jurisdictional claims in published maps and institutional affiliations.

Copyright: () 2022 by the authors. Licensee MDPI, Basel, Switzerland. This article is an open access article distributed under the terms and conditions of the Creative Commons Attribution (CC BY) license (https:// creativecommons.org/licenses/by/ $4.0 /)$.

\author{
Sanitary Engineering Laboratory, Department of Water Resources and Environmental Engineering, School of Civil \\ Engineering, National Technical University of Athens, Iroon Polytechniou 9, Zografou, 15780 Athens, Greece; \\ angalani90@gmail.com (A.G.); cnoutso@central.ntua.gr (C.N.); petrana.env@gmail.com (P.A.); \\ alexiavar@hotmail.com (A.V.) \\ * Correspondence: mamais@central.ntua.gr; Tel.: +30-210-772-2901
}

\begin{abstract}
Hexavalent chromium is a carcinogenic heavy metal that needs to be removed effectively from polluted aquifers in order to protect public health and the environment. This work aims to evaluate the reduction of $\mathrm{Cr}(\mathrm{VI})$ to $\mathrm{Cr}(\mathrm{III})$ in a contaminated aquifer through the stimulation of indigenous microbial communities with the addition of reductive agents. Soil-column experiments were conducted in the absence of oxygen and at hexavalent chromium $(\mathrm{Cr}(\mathrm{VI}))$ groundwater concentrations in the 1000-2000 $\mu \mathrm{g} / \mathrm{L}$ range. Two carbon sources (molasses and EVO) and one iron electron donor $\left(\mathrm{FeSO}_{4} \cdot 7 \mathrm{H}_{2} \mathrm{O}\right)$ were used as ways to stimulate the metabolism and proliferation of $\mathrm{Cr}(\mathrm{VI})$ reducing bacteria in-situ. The obtained results indicate that microbial anaerobic respiration and electron transfer can be fundamental to alleviate polluted groundwater from hazardous $\mathrm{Cr}(\mathrm{VI})$. The addition of organic electron donors increased significantly $\mathrm{Cr}(\mathrm{VI})$ reduction rates in comparison to natural soil attenuation rates. Furthermore, a combination of organic carbon and iron electron donors led to a longer life span of the remediation process and thus increased total $\mathrm{Cr}(\mathrm{VI})$ removal. This is the first study to investigate biotic and abiotic $\mathrm{Cr}(\mathrm{VI})$ removal by conducting experiments with natural soil and by applying biostimulation to modify the natural existing microbial communities.
\end{abstract}

Keywords: hexavalent chromium; anaerobic chromium reduction; biostimulation; organic and inorganic electron donors

\section{Introduction}

Chromium $(\mathrm{Cr})$ is a heavy metal that occurs in soils, sediments and groundwater through geogenic and anthropogenic sources. The main natural sources of $\mathrm{Cr}$ in the environment are ophiolithic and serpentine rocks, as well as their weathering products [1,2]. Anthropogenic $\mathrm{Cr}$ is mainly related to industrial processes, such as energy production, tanneries, ore-processing facilities, industrial metal processing, wood preservation, and to a lesser degree, agricultural activities [2-7]. Chromium compounds are usually found in two oxidation states. Trivalent chromium $\left(\mathrm{Cr}^{+3}\right)$ is a micronutrient used in some cases as a dietary supplement [8-11] and a stable form of $\mathrm{Cr}$, that has relatively low toxicity, forms insoluble substances, and is not able to cross cell membranes [12]. In contrast, hexavalent chromium $\left(\mathrm{CrO}_{4}{ }^{2-}, \mathrm{Cr}_{2} \mathrm{O}_{7}{ }^{2-}\right)$ is highly soluble, toxic and a well-known carcinogen $[13,14]$, that has been designated by the USEPA as one of seventeen chemicals posing the greatest

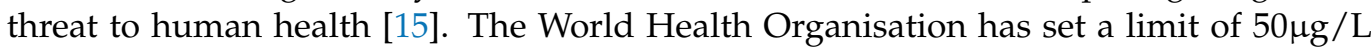
for total $\mathrm{Cr}$ in drinking water [16]. However, in several parts of the world reported values for geogenic $\mathrm{Cr}(\mathrm{VI})$ in aquifers can exceed that limit by tenths of $\mu \mathrm{g} / \mathrm{L}$, while anthropogenic $\mathrm{Cr}(\mathrm{VI})$ concentrations can exceed 10,000 $\mu \mathrm{g} / \mathrm{L}$, such as in the Asopos river basin in Greece [17-21]. Consequently, it is important to establish adequate treatment methods to rapidly reduce $\mathrm{Cr}(\mathrm{VI})$ to $\mathrm{Cr}$ (III) in $\mathrm{Cr}$-contaminated aquifers in order to protect the environment and public health. 
Traditional technologies for chromium removal from groundwater, such as adsorption, chemical reduction and precipitation, electrocoagulation and ion exchange, are rapid, effective and applicable to highly contaminated sites [22,23]. However, these techniques also present several disadvantages such as high capital and operational cost, production of hazardous by products, etc. [3,24-26]. On the contrary, biological reduction of hexavalent chromium is a cost effective, environmentally friendly and sustainable method of remediating polluted groundwater in situ, which can be achieved by stimulating the indigenous microbial populations in soils and/or groundwater through the addition of various carbon sources [26-28].

Biostimulation may exert a two-fold positive effect on $\mathrm{Cr}(\mathrm{VI})$ bioremediation efficiency. Carbon addition causes an increase in growth rates of indigenous bacteria that are able to directly reduce $\mathrm{Cr}(\mathrm{VI})$ biologically, through the production of chromate reductase [29-32] and the development of anaerobic conditions that result in the production of $\mathrm{Fe}^{+2}$ by iron reducing bacteria, which chemically reduces $\mathrm{Cr}(\mathrm{VI})$ to $\mathrm{Cr}(\mathrm{III})$ [33-35]. Thus by cycling minor amounts of iron, a significant amount of $\mathrm{Cr}(\mathrm{VI})$ could potentially be reduced to Cr(III) [36-39]. Therefore, stimulation of anaerobic processes in situ can be an effective treatment alternative for $\mathrm{Cr}(\mathrm{VI})$-polluted waters and has the potential for widespread application.

Several organic electron donors (acetate, glucose, lactate, yeast, etc.) have been tested for their potential to enhance $\mathrm{Cr}(\mathrm{VI})$ bioreduction $[40,41]$ and for their suitability for industrial scale application. Molasses and emulsified vegetable oil (EVO) are two organic substrates with different properties, that have recently gained ground as a means to remediate contaminated aquifers in situ. Molasses is a waste by product of sugarcane refining that contains sugars (sucrose, glucose and fructose) and small amounts of polyphenols and vitamins [42]. It is a low cost substance that at acidic $\mathrm{pH}$ can chemically reduce $\mathrm{Cr}(\mathrm{VI})$ to $\mathrm{Cr}(\mathrm{III})$, but at alkaline $\mathrm{pH}$ acts as a readily available carbon and energy source for microbes $[43,44]$. One major drawback is that it is rapidly biodegraded, thus requiring frequent injections to aquifers and increasing the operation costs [45,46]. In contrast, EVO are slowly soluble substrates, that ferment to acetate and hydrogen [47], thus providing longevity to the remediation process. However, their colloidal nature affects their mobility in porous materials $[48,49]$ and thus their effective distribution. Moreover, laboratory studies have shown that the presence of EVO decreases microbial richness and diversity [50]. In view of the above, the objective of this study was to assess the influence of two carbon electron donors (molasses and EVO) on potential in-situ microbial $\mathrm{Cr}(\mathrm{VI})$ reduction to $\mathrm{Cr}(\mathrm{III})$ and to investigate $\mathrm{Cr}(\mathrm{VI})$ reduction by a coupled biotic-abiotic pathway in the presence of iron reducing bacteria. In order to simulate closely natural conditions, we conducted column experiments with soil samples collected from the deep aquifer in the Asopos river basin region, while $\mathrm{Cr}(\mathrm{VI})$ groundwater concentrations were chosen in the $1000-2000 \mu \mathrm{g} / \mathrm{L}$ range to indicate the average pollution levels in this area. The ultimate goal of this particular study was to be able to propose a comprehensive, environmentally friendly and cost-effective way to remediate polluted aquifers in situ.

To the best of our knowledge this study is the first to investigate biotic and abiotic $\mathrm{Cr}(\mathrm{VI})$ removal by conducting experiments with natural soil and by applying biostimulation to modify the existing natural occurring bacteria. There are indeed some studies [50-52] that have studied $\mathrm{Cr}$ removal in column studies, however these studies employed biaugmentation and were conducted using sand columns. It should be underlined that biaugmentation acceptance at least in Europe is low due to time-consuming permits and regulations that require detailed risk assessment studies to prevent significant perturbations to the environment and contamination of native flora at a site [53].

\section{Materials and Methods}

\subsection{Descpription of Study Area}

The study area is located at the Asopos River Basin in the Region of Sterea Ellada, Greece. Asopos River Basin accounts for approximately $20 \%$ of the total national industrial 
production and experience significant pressures on both the quantity related to increased water abstraction and lowering the respective water levels, and quality related to pollution from point and diffusive sources. The surface and groundwater systems of the Asopos River Basin present high concentrations of chromium and hexavalent chromium both in surface waters and groundwater, a situation that has generated considerable public concern. The groundwater is used mostly for irrigation purposes, and to a lesser extent for drinking water supply. This research work stemmed from a LIFE project CHARM (http: / / www.charm-life.gr, accessed on 26 November 2021) that aimed to develop and apply remediation technologies and policy measures to protect groundwater from hexavalent Cr pollution in Asopos river basin. During the project a "hot spot" was identified in a heavily industrialized area at Inofyta in the Asopos river basin and a groundwater monitored program was carried out. For the hot spot identified, new boreholes were designed and properly constructed in strategically selected locations to monitor $\mathrm{Cr}(\mathrm{VI})$ pollution. The results confirmed the high $\mathrm{Cr}(\mathrm{VI})$ groundwater pollution mainly at Inofyta with $\mathrm{Cr}(\mathrm{VI})$ concentrations within the $6-10,103 \mu \mathrm{g} / \mathrm{L}$ range.

Soil samples used for the column experiments were collected from 28-28.5 m deep, transported to the lab and stored at $4{ }^{\circ} \mathrm{C}$. The soil main properties and components were determined with XRF analysis and are presented in Table 1 . The soil was sandy clay loam and its main components were $\mathrm{CaO}(30.03 \%)$ and $\mathrm{SiO}_{2}(19.04 \%)$. $\mathrm{Cr}$ and $\mathrm{Ni}$ were the main metals present (2195 mg/ $\mathrm{kg}$ and $1082 \mathrm{mg} / \mathrm{kg}$ respectively), which was expected, as the soil originated from a heavily contaminated industrialized area. The soil $\mathrm{pH}$ was 8.31.

Table 1. Properties and characteristics of the soil used in the column experiments.

\begin{tabular}{|c|c|}
\hline \multicolumn{2}{|c|}{ Main Geochemical Properties } \\
\hline \multirow{3}{*}{ Texture } & $58.8 \%$ Sand \\
\hline & 15.5\% Silt \\
\hline & $25.8 \%$ Clay \\
\hline Particle density $\left(\rho p, g / \mathrm{cm}^{3}\right)$ & 2.55 \\
\hline Specific surface area $\left(\mathrm{m}^{2} / \mathrm{g}\right)$ & 42.08 \\
\hline $\mathrm{pH}$ & 8.31 \\
\hline ORP $(\mathrm{mV})$ & 214.7 \\
\hline $\mathrm{NP}\left(\mathrm{g} \mathrm{CaCO}_{3} / \mathrm{kg}\right)$ & 583.4 \\
\hline $\mathrm{NP}(\mathrm{mol} \mathrm{CaCO} 3 / \mathrm{kg})$ & 5.83 \\
\hline Loss on ignition $(\%)$ & 26.72 \\
\hline Total carbon C ( $\%)$ & 7.02 \\
\hline Organic C (\%) & 0.16 \\
\hline \multicolumn{2}{|c|}{ Main Components (\%) } \\
\hline $\mathrm{CaO}$ & 30.03 \\
\hline $\mathrm{SiO}_{2}$ & 19.04 \\
\hline $\mathrm{MgO}$ & 9.50 \\
\hline $\mathrm{Fe}_{2} \mathrm{O}_{3}$ & 5.08 \\
\hline $\mathrm{Al}_{2} \mathrm{O}_{3}$ & 1.20 \\
\hline $\mathrm{Na}_{2} \mathrm{O}$ & 0.64 \\
\hline $\mathrm{MnO}$ & 0.13 \\
\hline \multicolumn{2}{|c|}{ Trace elements $(\mathrm{mg} / \mathrm{kg})$} \\
\hline $\mathrm{Cr}$ & 2195 \\
\hline $\mathrm{Ni}$ & 1082 \\
\hline Co & 118 \\
\hline $\mathrm{Ba}$ & 45 \\
\hline $\mathrm{Cu}$ & 21.1 \\
\hline $\mathrm{Cd}$ & 3.1 \\
\hline $\mathrm{Hg}$ & 2.5 \\
\hline As & $<20$ \\
\hline $\mathrm{Pb}$ & $<9$ \\
\hline
\end{tabular}




\subsection{Description of Lab-Scale Column System}

Experiments were carried out using two soil-filled up-flow columns made of cell cast acrylic material (plexiglass). The internal diameter of each column was $50 \mathrm{~mm}$ and the length $300 \mathrm{~mm}$. $\mathrm{Cr}(\mathrm{VI})$ solutions were kept in two $5 \mathrm{~L}$ anaerobic containers under an inert nitrogen atmosphere and a two head peristaltic pump (Shenchen LabM6, Baoding Shenchen Precision Pump Co., Ltd, Baoding, China) was used to connect the reactors with the columns. The soil columns were operating under saturated conditions with their pores entirely filled with water. The effluent of each column was recirculated into the container, in order to better simulate the conditions of an aquifer and its flow velocity. Flow was set at $1 \mathrm{~L}$ per day resulting to an average pore velocity of approximately $0.91 \mathrm{~m} /$ day. In order to avoid algae growth, the columns and the containers were wrapped with aluminum foil to prevent sun light penetration. The experimental set-up is shown in Figure 1. It should be underlined that the two columns were operated under identical conditions.

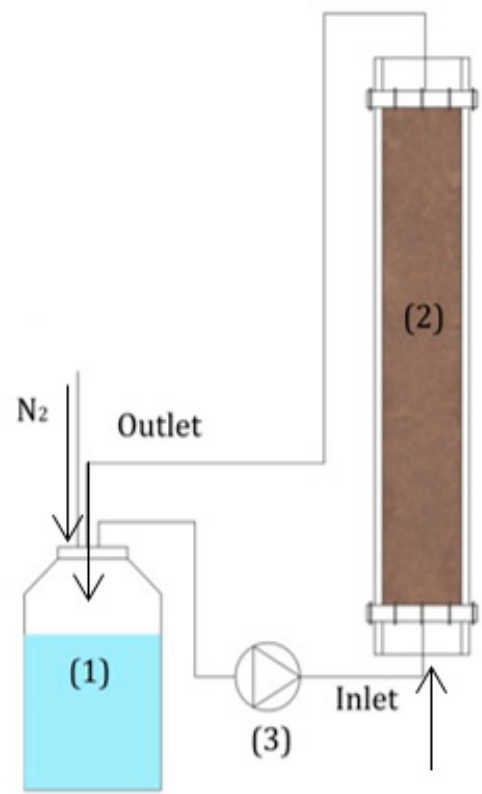

Figure 1. Scheme of the column lab-scale system: (1) $5 \mathrm{~L}$ Container with $\mathrm{Cr}(\mathrm{VI})$ solution, (2) Column filled with soil, (3) Peristaltic pump.

\subsubsection{Soil Pretreatment and Filling Procedure of Columns}

Prior to the commencement of the experiments, soil was air-dried and the soil agglomerates were broken down by gently tapping with a hammer. The experiments were conducted using the soil fraction $(<2 \mathrm{~mm})$ as the work sample. The soil was placed manually in the columns and gently vibrated at several stages to ensure uniform packing. The detailed properties of the columns are given in Table 2.

Table 2. Column properties and operating conditions.

\begin{tabular}{lcc}
\hline \multirow{2}{*}{ Parameter } & \multicolumn{2}{c}{ Soil Column } \\
\cline { 2 - 3 } & I & II \\
\hline Soil weight, $\mathrm{M}(\mathrm{g})$ & 649 & 670 \\
Column internal diameter, d $(\mathrm{mm})$ & 50 & 50 \\
Column height, $\mathrm{L}(\mathrm{mm})$ & 300 & 300 \\
Bed Volume, $\mathrm{BV}\left(\mathrm{cm}^{3}\right)$ & 589 & 589 \\
Dry bulk density, $\rho_{\mathrm{p}}\left(\mathrm{g} / \mathrm{cm}^{3}\right)$ & 1.102 & 1.137 \\
Porosity, $\theta$ & 0.568 & 0.554 \\
Pore Volume, $\mathrm{Vpv}\left(\mathrm{cm}^{3}\right)$ & 334.54 & 326.30 \\
Filter & Glass wool & Glass wool \\
\hline
\end{tabular}




\subsubsection{Preparation of Experimental Solutions}

To perform the experiments, three distinctive aqueous solutions were prepared. The organic load solution was prepared by dissolving $0.2 \mathrm{~g}$ concentrated molasses (Thermo Fischer Scientific, Waltham, MA, USA) and $0.8 \mathrm{~g}$ of concentrated EVO (JRW Bioremediation, L.L.C., Lenexa, KS, USA) to 1L of filtered groundwater in order to achieve a total COD of approximately $1600 \mathrm{mg} / \mathrm{L}$. Properties and characteristics of molasses and EVO are presented in Table 3. Molasses and EVO were added as a mixture in order to provide immediate stimulation to the microbial community and enable microbial diversity. For the ferrous iron solution, $312 \mathrm{mg}$ of ferrous sulfate heptahydrate (Thermo Fischer Scientific) was dissolved in $1 \mathrm{~L}$ distilled water which was previously pre-treated with nitrogen gas to remove dissolved oxygen. The columns were fed with a $\mathrm{K}_{2} \mathrm{Cr}_{2} \mathrm{O}_{7}$ solution (Sigma-Aldrich, St. Louis, MO, USA) that was prepared with filtered groundwater, in which hexavalent chromium was added, at an initial concentration of 1000-2000 ppb. All groundwater used in the experiments was from the National Technical University of Athens campus water supply network.

Table 3. Properties and characteristics of molasses and EVO used in the experiments.

\begin{tabular}{ccc}
\hline Properties & Molasses & Emulsified Vegetable Oil \\
\hline Molecular Formula & $\mathrm{C}_{6} \mathrm{H}_{12} \mathrm{NNaO}_{3} \mathrm{~S}$ & $\mathrm{CH}_{3}-\mathrm{CHOH}-\mathrm{COONa}$ \\
Appearance/Physical state & Dark brown liquid & Clear to light yellow liquid \\
Components & - & $60 \%$ Lactate $/ 40 \%$ Water \\
Density & $1.4 \mathrm{~g} / \mathrm{mL}$ & - \\
Viscosity & - & $100 \mathrm{cP}\left(\right.$ at $\left.20{ }^{\circ} \mathrm{C}\right)$ \\
Molecular weight & $201.22 \mathrm{~g} / \mathrm{mol}$ & $112.07 \mathrm{~g} / \mathrm{mol}$ \\
pH & 5.1 & $6.0-8.5$ \\
\hline
\end{tabular}

\subsection{Experimental Methods}

\subsubsection{Start-Up Protocol}

In order to achieve soil enrichment with native microorganisms, each column was saturated with unfiltered groundwater from the National Technical University of Athens campus water supply network and incubated under anaerobic conditions for 14 days.

\subsubsection{Control Experiment}

After the start-up period, both columns were supplied for two weeks via recirculation with a $4 \mathrm{~L} \mathrm{Cr}(\mathrm{VI})$ solution in order to evaluate the reductive capacity of each soil column without the addition of any reducing agent.

\subsubsection{Bio-Stimulation Experiment}

To evaluate biologically induced $\mathrm{Cr}(\mathrm{VI})$ removal, an aqueous solution that contained the necessary organic load for the biological processes was recirculated in the two columns for 2 days. The experiment then proceeded by continuously recycling $\mathrm{Cr}(\mathrm{VI})$ solution without the addition of any reducing agent, that had an initial volume of $4 \mathrm{~L}$ and a $\mathrm{Cr}(\mathrm{VI})$ concentration of $1000 \mu \mathrm{g} / \mathrm{L}$. During each run the initial $\mathrm{Cr}(\mathrm{VI})$ concentration was equal to approximately $1 \mathrm{mg} / \mathrm{L}$ and each run was carried out till $\mathrm{Cr}(\mathrm{VI})$ was completely removed from the feeding solution. This part of the experiment continued until the columns' $\mathrm{Cr}(\mathrm{VI})$ reducing capabilities decreased significantly. Samples from the inlet and the outlet of the columns were analysed frequently and the results were recorded for further processing.

\subsubsection{Biotic-Abiotic Cr(VI) Removal Experiment}

The objective of this experimental series was to evaluate the potential reduction of $\mathrm{Fe}(\mathrm{III})$ to $\mathrm{Fe}(\mathrm{II})$ (Fe(II) regeneration) with the addition of organic carbon sources and to study a coupled biological and chemical $\mathrm{Cr}(\mathrm{VI})$ removal pathway. In order to accomplish this, each column was supplied at first with $1 \mathrm{~L}$ of the ferrous iron solution for one day. After the 1 day feeding period, contaminated groundwater containing $1000 \mu \mathrm{g} / \mathrm{L} \mathrm{Cr}(\mathrm{VI})$, was 
introduced in the columns without e addition of any reducing agent and the outlet of the column was returned in the feed tank and then recycled back to the column continuously. This part of the experiment continued until no further $\mathrm{Cr}(\mathrm{VI})$ removal was reported. The experiment proceeded by supplying the columns with the organic donors solution, as was described in Section 2.2.2. The experiment continued by recirculating $4 \mathrm{~L}$ of groundwater with 1000-2000 ppb hexavalent chromium concentration. The reductive capacity of both columns was re-evaluated by collecting samples frequently from the inlet and the outlet of the columns.

\subsection{Analytical Procedures}

Samples were collected frequently from inlet and outlet of the columns and were analyzed for $\mathrm{pH}, \mathrm{DO}$, total and hexavalent chromium, total and soluble COD and ferrous iron Fe(II). The parameters of $\mathrm{pH}$ and DO were determined by a WTW ${ }^{\mathrm{TM}}$ MultiLine ${ }^{\mathrm{TM}} 3410$ Portable Digital Multiparameter (Fisher Scientific, Göteborg, Sweden). Throughout the experiments, $\mathrm{pH}$ did not exhibit any significant changes and was approximately $8.37 \pm 0.11$, while DO was determined in order to verify the anaerobic conditions in the column systems. Total chromium was determined by a LCS313 Hach cuvette test [54]. Chromate in solution was measured colorimetrically using the USEPA 7196a method (1,5-diphenylcarbazide method) [55]. COD was determined by USEPA approved standard method 5220 D [56]. Ferrous iron Fe(II) was determined by the 1,10-phenanthroline method [57].

Soil permeability was determined by applying the constant head permeability test based on the principle of Darcy's Law [58]. Permeability was calculated as follows:

$$
\mathrm{K}=\mathrm{V} \times \mathrm{L} /(\mathrm{A} \times \Delta \mathrm{H} \times \mathrm{t}),
$$

where K: coefficient of permeability $(\mathrm{cm} / \mathrm{s}), \mathrm{V}$ : collected volume of water $(\mathrm{mL}), \Delta \mathrm{H}$ : head difference $(\mathrm{cm})$, L: length of soil sample $(\mathrm{cm})$, t: time required to collect $V$ volume $(\mathrm{s})$ and A: cross sectional of the soil sample $\left(\mathrm{cm}^{2}\right)$.

The test was carried out on soil samples with $\mathrm{A}=19.63 \mathrm{~cm}^{2}, \Delta \mathrm{H}=104.5 \mathrm{~cm}$ and length $\mathrm{L}=30 \mathrm{~cm}$ (compacted at dry bulk density equal to $1.102 \mathrm{~g} / \mathrm{cm}^{3}$ and $1.137 \mathrm{~g} / \mathrm{cm}^{3}$ respectively for Columns I and II). Measurements were repeated three times. Soil permeability was measured immediately before the experiments commenced and after they concluded, with the exception of the biotic-abiotic experiment, where it was also evaluated immediately after the addition of ferrous iron.

In order to identify the different groups of microbes that participated in $\mathrm{Cr}(\mathrm{VI})$ reduction, FISH method was employed according to the protocol described by Mamais et al. [59] and Panousi et al. [60]. Liquid samples were collected immediately after the Control experiment and after the biotic-abiotic $\mathrm{Cr}(\mathrm{VI})$ removal experiment. The probes used, as well as the formamide and $\mathrm{NaCl}$ concentrations are shown in Table 4. Microscopic observations were carried out at $1000 \times$ magnification utilising an epifluorescence microscope (E50i, Nikon Instruments Inc., Melville, NY, USA). The results were estimated as ratios of target probe/total DAPI stained cells. 
Table 4. Probes used for FISH analysis.

\begin{tabular}{|c|c|c|c|c|}
\hline Target Microorganisms & Oligonucleotide Probe & Sequence $\left(5^{\prime}\right.$ to $\left.3^{\prime}\right)$ & $\begin{array}{c}\text { Formamide } \\
\text { Concentration } \\
(\% v / v)\end{array}$ & Reference \\
\hline Most Bacteria & EUB338 & GCT GCC TCC CGT AGG AGT & 35 & {$[61]$} \\
\hline Most Archaea & ARCH915 & GTG CTC CCC CGC CAA TTC CT & 35 & [62] \\
\hline $\begin{array}{l}\text { Methanosarcina \& } \\
\text { Methanosaeta spp. }\end{array}$ & MSMX860 & GGC TCG CTT CAC GGC TTC CCT & 45 & [63] \\
\hline Gammaproteobacteria & GAM42a & GCC TTC CCA CAT CGT TT & 35 & {$[64]$} \\
\hline Deltaproteobacteria & DELTA495a & AGT TAG CCG GTG CTT CCT & 35 & {$[65]$} \\
\hline $\begin{array}{l}\text { Desulfobacteraceae \& } \\
\text { Syntrophobacteraceae }\end{array}$ & DSBAC357 & CCA TTG CGC AAA ATT CCT CAC & 35 & [66] \\
\hline Acetobacterium spp & AW & GGC TAT TCC TTT CCA TAG GG & 30 & [67] \\
\hline Geobacter spp. & GEO3A & CCG CAA CAC CTA GTA CTC ATC & 30 & {$[68]$} \\
\hline Desulfovibrio spp. & SRB687 & TAC GGA TTT CAC TCC T & 15 & [69] \\
\hline
\end{tabular}

\subsection{Data Calculation}

The experimental data from the inlet of both columns were plotted in graphs with the values $\ln \left(C_{t} / C_{\text {initial }}\right)$ versus time, in order to evaluate the first order equation constant $\left(\mathrm{k}_{\mathrm{Cr}(\mathrm{VI})}\right)$, describing $\mathrm{Cr}(\mathrm{VI})$ removal:

$$
\begin{aligned}
& \ln \left(\frac{\mathrm{C}_{\mathrm{t}}}{\mathrm{C}_{\text {initial }}}\right)=-\mathrm{k} \times \mathrm{t}, \\
& \mathrm{k}=\mathrm{k}_{\mathrm{Cr}(\mathrm{VI})} \times\left(\frac{\mathrm{V}_{\text {soil }}}{\mathrm{V}_{\text {liquid }}}\right),
\end{aligned}
$$

where $\mathrm{C}_{\text {initial }}$ : initial $\mathrm{Cr}(\mathrm{VI})$ concentration at the start of the experiments $(\mathrm{mg} / \mathrm{L}), \mathrm{C}_{\mathrm{t}}: \mathrm{Cr}(\mathrm{VI})$ concentration over time remaining in the recycling solution $(\mathrm{mg} / \mathrm{L})$, $\mathrm{t}$ : time/the experimental day at each run, $\mathrm{k}$ : slope of the linear trendline produced on the graphs, $\mathrm{k}_{\mathrm{Cr}(\mathrm{VI})}$ : the first order $\mathrm{Cr}(\mathrm{VI})$ removal constant $\left(\mathrm{d}^{-1}\right), \mathrm{V}_{\text {soil }} / \mathrm{V}_{\text {liquid }}$ : volume ratio between the soil and the water that was treated.

The parameter $\mathrm{V}_{\text {soil }} / \mathrm{V}_{\text {liquid }}$ was employed to represent the fact that at higher soils to water ratios the water comes in contact with a higher amount of soil that contains the added reducing agents and therefore is expected to remove $\mathrm{Cr}(\mathrm{VI})$ at a higher rate. In a saturated aquifer the $\mathrm{V}_{\text {soil }} / \mathrm{V}_{\text {liquid }}$ can be calculated based on the porosity by the following equation:

$$
\left(\mathrm{V}_{\text {soil }} / \mathrm{V}_{\text {liquid }}\right)=((1-\Theta) / \Theta),
$$

where $\Theta$ is the porosity of the soil.

The graphs used for the determination of the $\mathrm{k}_{\mathrm{Cr}(\mathrm{VI})}$ constant are provided in Supplementary Material (Figures S1-S8).

The biotic experiments were conducted at room temperature at $17^{\circ} \mathrm{C} \pm 2$, whereas the rest were carried out at $25^{\circ} \mathrm{C} \pm 2$. The reduction rates from the biotic experiments were corrected at $25^{\circ} \mathrm{C} \pm 2$ using the Arrhenius equation.

$$
\mathrm{k}=\mathrm{A} \times \exp \left[-\mathrm{E}_{\mathrm{a}} /(\mathrm{R} \times \mathrm{T})\right],
$$

where $\mathrm{k}$ : $\mathrm{Cr}(\mathrm{VI})$ removal rate $\left(\mathrm{d}^{-1}\right), \mathrm{A}$ : a frequency factor $\left(\mathrm{d}^{-1}\right), \mathrm{E}_{\mathrm{a}}$ : activation energy of the process $(\mathrm{J} / \mathrm{mol}), \mathrm{R}$ : the ideal gas constant $(8.314 \mathrm{~J} / \mathrm{mol} / \mathrm{K})$, T: temperature (Kelvin).

Values for the correction were used from studies for chromium bioreduction under anaerobic conditions $[59,70,71]$. 


\section{Results and Discussion}

\subsection{Natural Soil Capacity Experiment (Control)}

During the control experiments, the overall natural $\mathrm{Cr}(\mathrm{VI})$ removal capacity of the soil was very low (approximately $1.12 \pm 0.21 \mathrm{mg}(\mathrm{Cr}(\mathrm{VI}) / \mathrm{kg}$ soil). As observed in Figure 2, the inlet $\mathrm{Cr}(\mathrm{VI})$ concentrations remained close to the spiked concentration throughout the experiment. The $\mathrm{k}_{\mathrm{Cr}(\mathrm{VI})}$ removal rate was approximately $0.16 \pm 0.05 \mathrm{~d}^{-1}$. Other soil column laboratory studies carried out with sterile and non-sterile soils have reported similarly low $\mathrm{Cr}(\mathrm{VI})$ removal rates $[50,72]$.

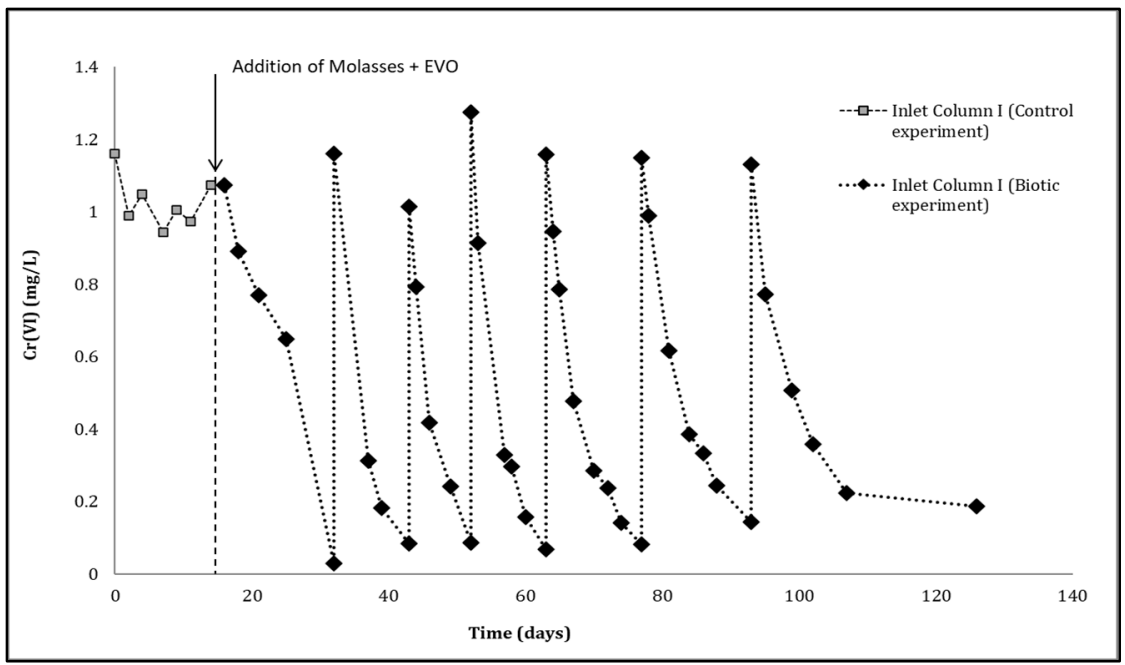

(a)

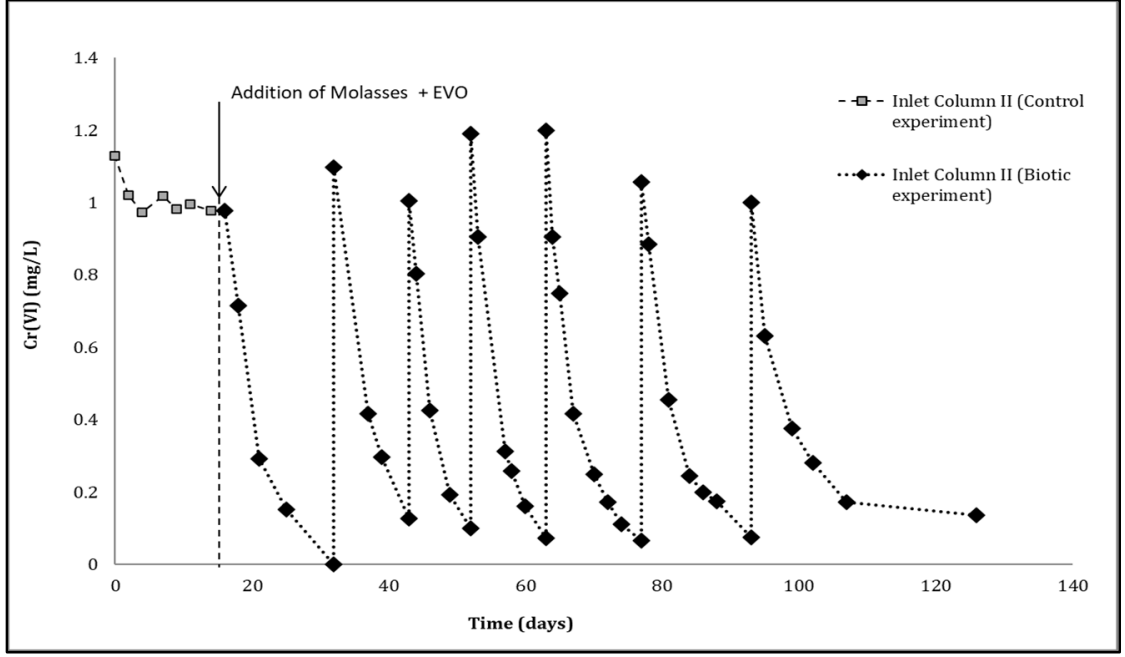

(b)

Figure 2. $\mathrm{Cr}(\mathrm{VI})$ profiles in the inlet of Columns I (a) and II (b) during the control and bio-enhancement experiments.

\subsection{Influence of Organic Electron Donors in Cr(VI) Bio-Reduction}

$\mathrm{Cr}(\mathrm{VI})$ biotic removal capacity of both columns was evaluated by feeding with $\mathrm{Cr}(\mathrm{VI})$ contaminated groundwater for 110 days following the protocol described in Section 2.3.3. Overall, seven experimental runs were conducted during this period. During each run the initial $\mathrm{Cr}(\mathrm{VI})$ concentration was equal to approximately $1000 \mu \mathrm{g} / \mathrm{L}$ and each run was carried out until at least $90 \%$ of $\mathrm{Cr}(\mathrm{VI})$ concentration was removed from solution. The total COD retained in the columns from the 2-day feeding period, the total amount of $\mathrm{Cr}(\mathrm{VI})$ reduced and the total biotic $\mathrm{Cr}(\mathrm{VI})$ removal are shown in Table 5. Comparing the experimental 
results from the two columns, it is shown that both exhibited the same behaviour. During each run, as illustrated in Figure 2, the biostimulated microbial community grown in the soil matrix was able to completely remove $\mathrm{Cr}(\mathrm{VI})$ from the feed solution in approximately twelve days (runs 2-6). Excluding the last run, where the organic $\mathrm{e}^{-}$donor was completely depleted, the biotic $\mathrm{Cr}(\mathrm{VI})$ removal rates ranged from 1.74 to $4.35 \mathrm{~d}^{-1}$, while the majority of them was in the $3-4 \mathrm{~d}^{-1}$ range (36\%). Comparing these results with the results from the Control experiment, biostimulation was achieved and removal rates increased up to 20 times.

Table 5. Experimental results from the biotic experiment.

\begin{tabular}{clcc}
\hline \multirow{2}{*}{ Experiment } & \multicolumn{1}{c}{ Parameter } & \multicolumn{2}{c}{ Soil Column } \\
\cline { 3 - 4 } & & I & II \\
\hline \multirow{3}{*}{ Biotic experiment } & Retained COD (mg COD/kg soil) & 1834 & 1798 \\
& Duration of experiment (days) & 110 & 110 \\
& No of experimental runs & 7 & 7 \\
& Mass of reduced Cr(VI) $(\mathrm{mg})$ & 22.41 & 21.06 \\
& Total Cr(VI) removal (mg Cr(VI)/kg soil) & 34.53 & 31.44 \\
& Soil permeability reduction (End of & 44.92 & 63.32 \\
& experiment) $(\%)$ & & \\
\hline
\end{tabular}

Addition of single organic electron donors such as molasses or EVO has been evaluated in several laboratory scale studies $[40,44,45,49-51,73]$. Results from previous studies are in agreement with the findings of this work and indicate that both carbon sources are able to support complete $\mathrm{Cr}(\mathrm{VI})$ reduction even at high initial $\mathrm{Cr}(\mathrm{VI})$ concentrations, that far exceed pollution levels in the environment.

\subsection{Biotic-Abiotic Cr(VI) Removal}

In order to examine the hypothesis that the addition of carbon sources in the presence of iron results in the development of reducing conditions and the stimulation of iron reducing bacteria that leads to a constant production of Fe(II), columns experiments were carried out as described in Section 2.3.4. The experiments were conducted in two phases: during the 1st phase only abiotic $\mathrm{Cr}(\mathrm{VI})$ removal was evaluated while during the 2nd phase combined abiotic-biotic $\mathrm{Cr}(\mathrm{VI})$ removal was studied.

\subsubsection{Abiotic $\mathrm{Cr}(\mathrm{VI})$ Removal}

Initially both columns were fed with $1 \mathrm{~L}$ of ferrous iron solution (concentration of $50 \mathrm{mg} / \mathrm{L} \mathrm{Fe}^{+2}$ ) for 1 day and $\mathrm{Cr}(\mathrm{VI})$ contaminated groundwater for 45 days. As shown in Figure 3a,b ferrous sulfate addition resulted in $\mathrm{Cr}(\mathrm{VI})$ removal from groundwater by $\mathrm{Cr}$ (VI) reduction, adsorption and co-precipitation. However the efficiency of the abiotic removal was very limited and was approximately $0.77-2.52 \mathrm{mg} \mathrm{Cr}(\mathrm{VI})$, because a large portion of Fe(II) added was passivated decreasing the overall performance and longevity of the process. The results also indicated that the reductive capability of column I was slightly better than column II, although that difference was not significant. 


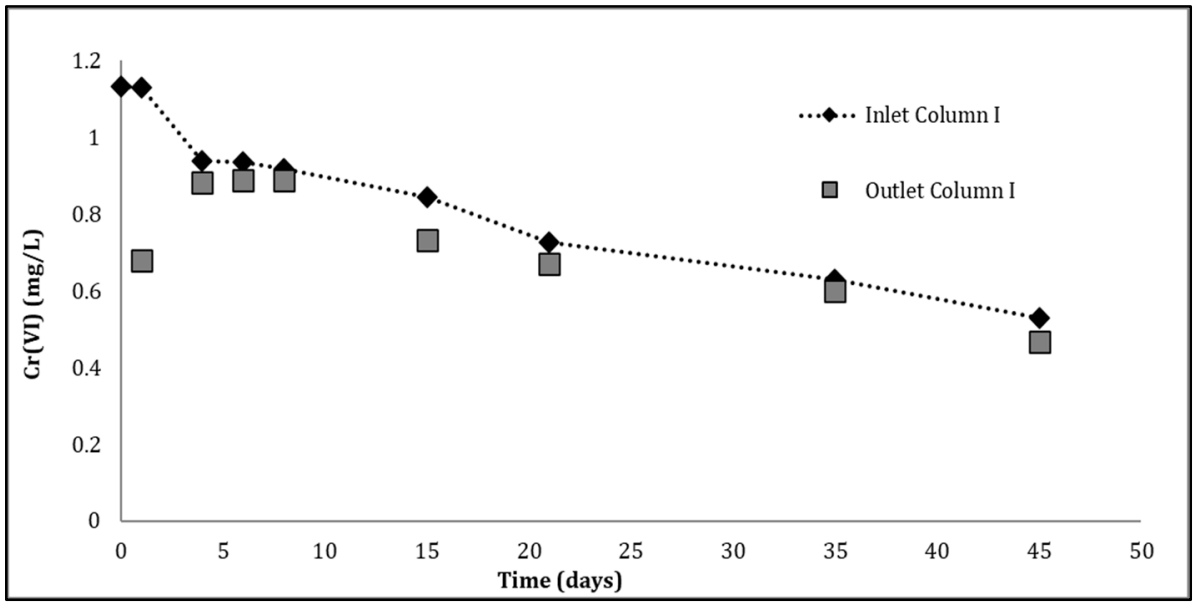

(a)

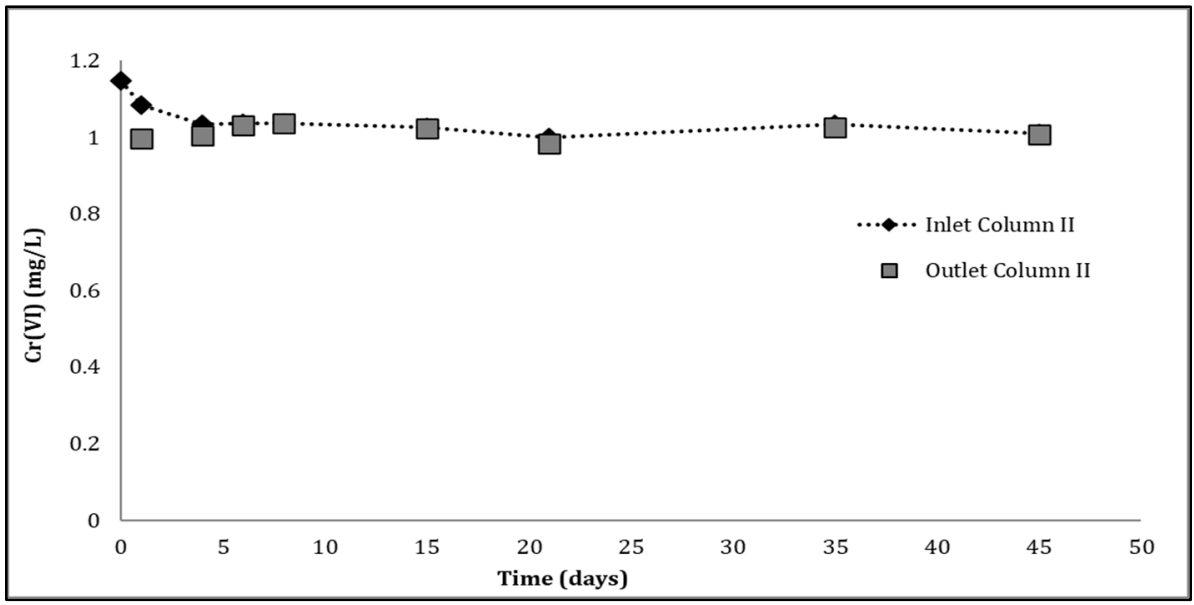

(b)

Figure 3. $\mathrm{Cr}(\mathrm{VI})$ profiles in the inlet and outlet of Columns I (a) and II (b) after the addition of ferrous iron.

Hexavalent chromium and ferrous iron react chemically as follows, producing nontoxic trivalent chromium:

$$
0.25 \mathrm{CrO}_{4}^{2-}(\mathrm{aq})+0.75 \mathrm{Fe}^{2+}(\mathrm{aq})+2 \mathrm{H}_{2} \mathrm{O} \rightarrow \mathrm{Cr}_{0.25} \mathrm{Fe}_{0.75}(\mathrm{OH})_{3}(\text { solid })+\mathrm{H}^{+}
$$

Taking into consideration that the theoretical stoichiometric ratio of $\mathrm{Cr}(\mathrm{VI})$ removal is $0.31 \mathrm{gCr}(\mathrm{VI}) / \mathrm{gFe}(\mathrm{II})$ added, it is obvious that most of $\mathrm{Fe}(\mathrm{II})$ added was unavailable for $\mathrm{Cr}(\mathrm{VI})$ reduction. The soil and groundwater $\mathrm{pH}(8.37 \pm 0.11)$ and composition, favour the formation of iron containing solids, such as siderite $\left(\mathrm{FeCO}_{3}\right)$, ferrous sulfide ( $\left.\mathrm{FeS}\right)$, pyrite $\left(\mathrm{FeS}_{2}\right)$, and according to the data of this study, less than $16 \%$ of ferrous iron was soluble and thus effective. It is noted that no ferrous iron was detected in the inlet and outlet of the columns. Visual inspection of the soil in the column also showed that a brown-red solid was formed inside the soil column that reached less than $20 \%$ of the total column length, indicating the formation of $\mathrm{FeCO}_{3}$ and that $\mathrm{Fe}(\mathrm{II})$ had limited mobility in this soil matrix.

\subsubsection{Combined Biotic-Abiotic Cr(VI) Removal}

Following the exhaustion of abiotic $\mathrm{Cr}(\mathrm{VI})$ removal the two columns were fed for two days with organic electron donors to study combined abiotic and biotic $\mathrm{Cr}(\mathrm{VI})$ removal. Figure 4 and Table 6 show the results from the two columns following addition of the organic electron donors. The columns were fed with $\mathrm{Cr}(\mathrm{VI})$ contaminated groundwater until the columns reductive capabilities were almost completely exhausted. During the 
first eight runs, the initial $\mathrm{Cr}(\mathrm{VI})$ concentration was equal to approximately $1000 \mu \mathrm{g} / \mathrm{L}$. Due to the significant $\mathrm{Cr}(\mathrm{VI})$ removal efficiency of both columns the remaining runs were conducted with an initial $\mathrm{Cr}(\mathrm{VI})$ concentration that was approximately $2000 \mu \mathrm{g} / \mathrm{L}$. In Column I, total $\mathrm{Cr}(\mathrm{VI})$ removal was $26 \%$ higher in comparison to Column II and the experiment lasted for 30 more days. As shown in Figure $4 a, b$, both columns were able to completely remove $\mathrm{Cr}(\mathrm{VI})$ from the feed solution in approximately eight days. Furthermore, $\mathrm{Cr}(\mathrm{VI})$ concentration in column outlets was usually not detected. Excluding the last run, where the organic $\mathrm{e}^{-}$donor was exhausted, $\mathrm{Cr}(\mathrm{VI})$ removal rates ranged from 2.44 to $7.38 \mathrm{~d}^{-1}$, while the majority of them was between the $3-4 \mathrm{~d}^{-1}$ range (50\%).

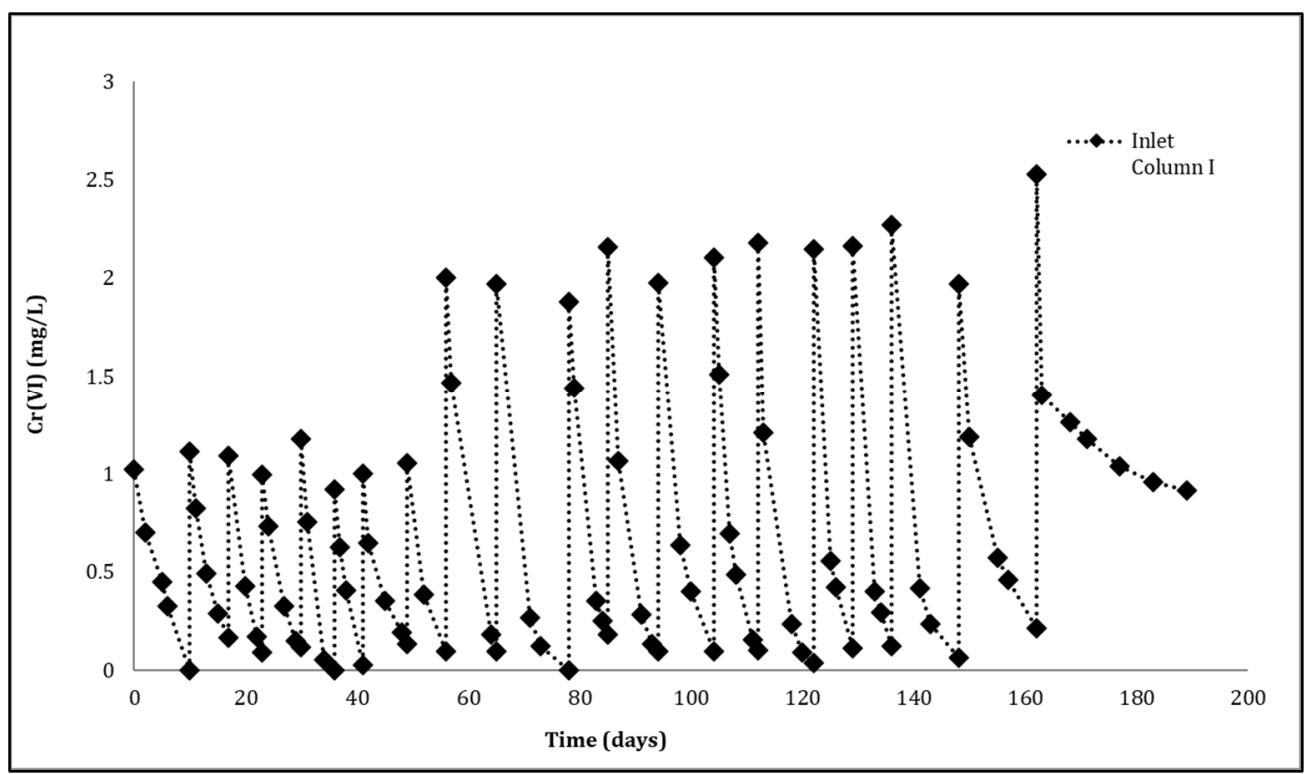

(a)

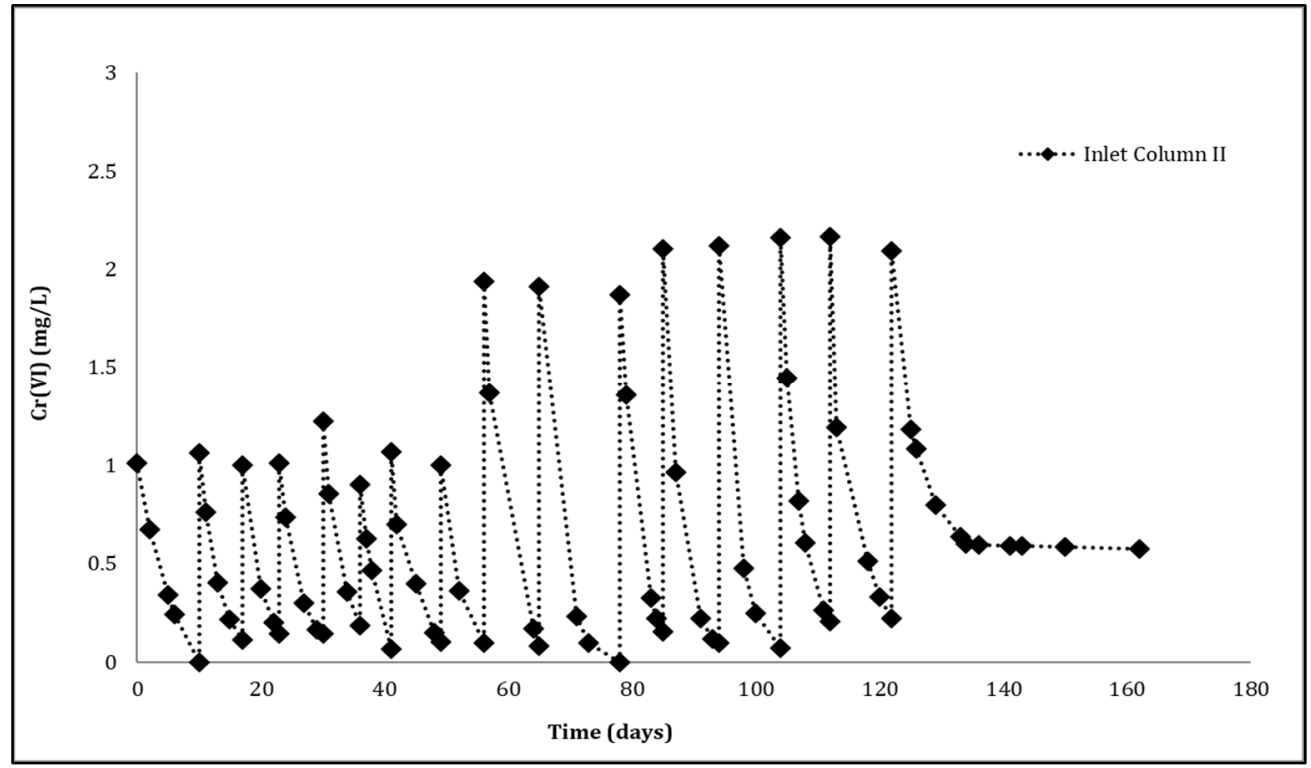

(b)

Figure 4. $\mathrm{Cr}(\mathrm{VI})$ profiles in the inlet of Columns I (a) and II (b) in the Biotic-Abiotic experiment after the addition of the carbon sources. 
Table 6. Experimental results from the Biotic-Abiotic experiment.

\begin{tabular}{clcc}
\hline \multirow{2}{*}{ Experiment } & \multicolumn{1}{c}{ Parameter } & \multicolumn{2}{c}{ Soil Column } \\
\cline { 3 - 4 } & & I & II \\
\hline & Retained COD (mg COD/kg soil) & 2354 & 2360 \\
& Duration of experiment (days) & 189 & 162 \\
& No of experimental runs & 20 & 16 \\
Biotic-Abiotic & Mass of reduced Cr(VI) $(\mathrm{mg})$ & 82.8 & 63.2 \\
experiment & Total Cr(VI) removal $(\mathrm{mg} \mathrm{Cr}(\mathrm{VI}) / \mathrm{kg}$ soil) & 127.51 & 94.27 \\
& $\begin{array}{l}\text { Soil permeability reduction immediately } \\
\text { after the addition of Fe }(\%)\end{array}$ & 16.63 & 16.73 \\
& Soil permeability reduction (End of & & \\
& experiment) $(\%)$ & 89.91 & 94.33 \\
\hline
\end{tabular}

FISH analysis (Figure 5) indicated a shift in the microbial community after the addition of the organic and inorganic electron donors. Eubacteria remained the predominant microorganism throughout the experiment, however, at the end of the experiment Archaea had increased from 5\% to 35\%, while Methanosarcina spp. and Methanosaeta spp. increased from $0.5 \%$ to $16 \%$. This increase was apparently due to the establishment of anaerobic conditions. Geobacter spp., Gammaproteobacteria and Deltaproteobacteria remained minimal throughout the experiment since nitrates and sulfates were not present in the solution.

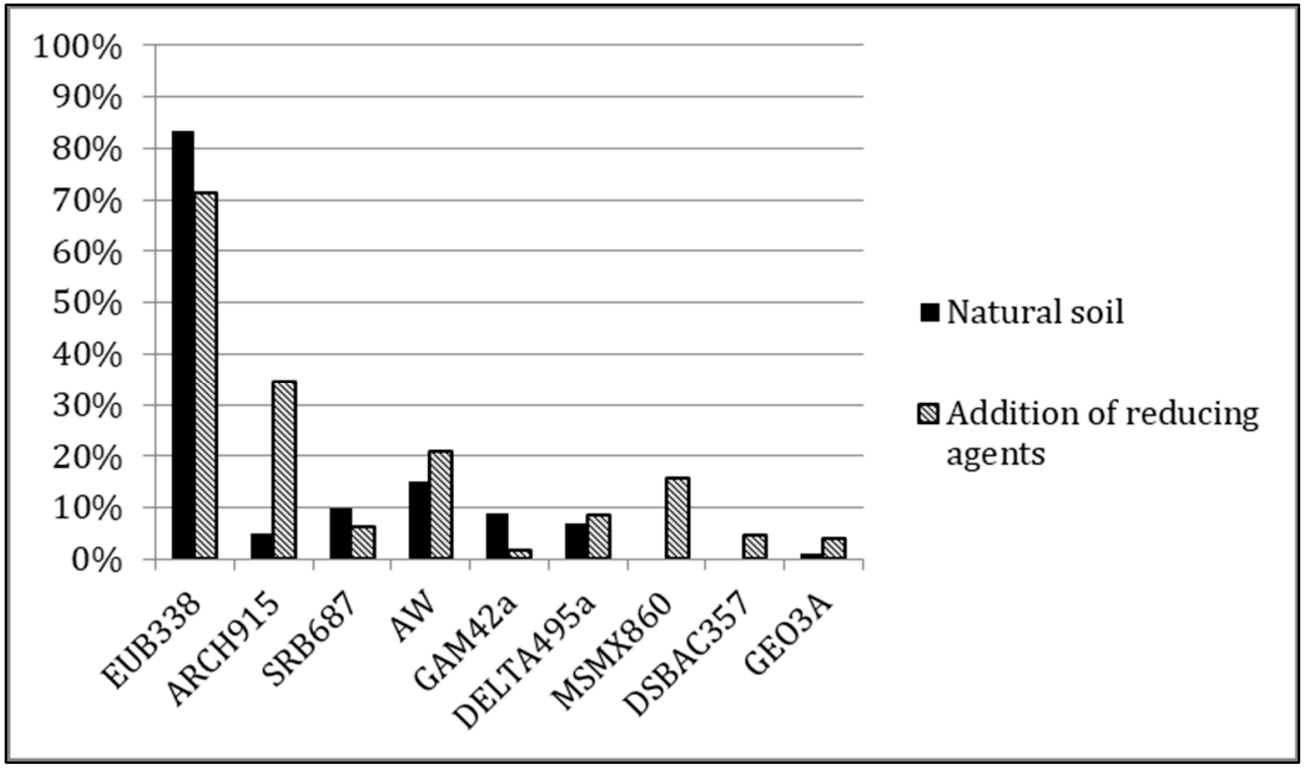

Figure 5. FISH microbial analysis results on natural soil and after the addition of the reducing agents (Molasses, $\mathrm{EVO}$ and $\mathrm{FeSO}_{4}$ ).

\subsection{Comparison between Biotic and Biotic-Abiotic Experiment}

Figure 6 depicts $\mathrm{Cr}(\mathrm{VI})$ removal rates from the biotic and the biotic-abiotic experiments for each experimental cycle. Comparing the removal rates from the two experiments, it is observed that during the first four experimental runs, $\mathrm{k}_{\mathrm{Cr}(\mathrm{VI})}$ are similar for both experiments (3.90 $\pm 0.35 \mathrm{~d}^{-1}$ and $4.38 \pm 0.63 \mathrm{~d}^{-1}$ respectively). However, after the 5 th run they exhibited completely different behavior. In the biotic experiment, the removal rate declines gradually until the termination of the experiment on the 7 th run where it reaches $0.64 \pm 0.01 \mathrm{~d}^{-1}$. On the other hand, the biotic-abiotic experiment lasted much longer, 16-20 runs, with the removal rates increasing considerably in the 5th and 6th run $\left(5.42 \pm 2.35\right.$ and $6.24 \pm 1.61$ respectively), while remaining in the $3-4 \mathrm{~d}^{-1}$ range for the whole duration of the biotic-abiotic experiment. Therefore, although the addition of Fe(II) combined with molasses and EVO appear not to exert a significant effect on the magnitude 
of the $\mathrm{Cr}(\mathrm{VI})$ removal rate, it affects positively the longevity of the remediation process. Moreover, the combined abiotic and biotic removal resulted in a much longer life span that exceeded by approximately $48-72 \%$ the biotic removal. In addition, coupled biotic and abiotic process demonstrated a $67-73 \%$ increase in total $\mathrm{Cr}(\mathrm{VI})$ removal $(\mathrm{mg} \mathrm{Cr}(\mathrm{VI}) / \mathrm{kg}$ soil). The experimental results illustrate that the addition of organic electron donors can lead to the regeneration of $\mathrm{Fe}$ (II) and the coupled abiotic and biotic processes can significantly improve $\mathrm{Cr}(\mathrm{VI})$ removal from groundwater. Wen et.al [50] have reported that the presence of EVO substrates improves microbial dissimilatory $\mathrm{Fe}^{+3}$ reduction, resulting in higher $\mathrm{Fe}^{+2}$ production. Furthermore, according to several studies [74-76], anaerobic microbial processes improve abiotic $\mathrm{Cr}(\mathrm{VI})$ reduction by $\mathrm{Fe}(\mathrm{II})$ by generating highly reactive minerals such as mackinawite, green rusts and magnetite, which may favour the removal of $\mathrm{Cr}(\mathrm{VI})$ by mechanisms such as adsorption, co-precipitation and/or reduction. It should be noted that the analyses performed during the course of the experiment demonstrated that $\mathrm{Fe}^{+2}$ concentration was less than $0.2 \mathrm{mg} / \mathrm{L}$ (detection limit) at both the inlet and the outlet of the columns, which is explained by (a) the limited mobility of iron in this particular soil matrix, (b) the fact that in the presence of $\mathrm{Cr}^{+6}, \mathrm{Fe}(\mathrm{II})$ was oxidized to $\mathrm{Fe}(\mathrm{III})$ and (c) the potential creation of Cr-Fe complexes [51].

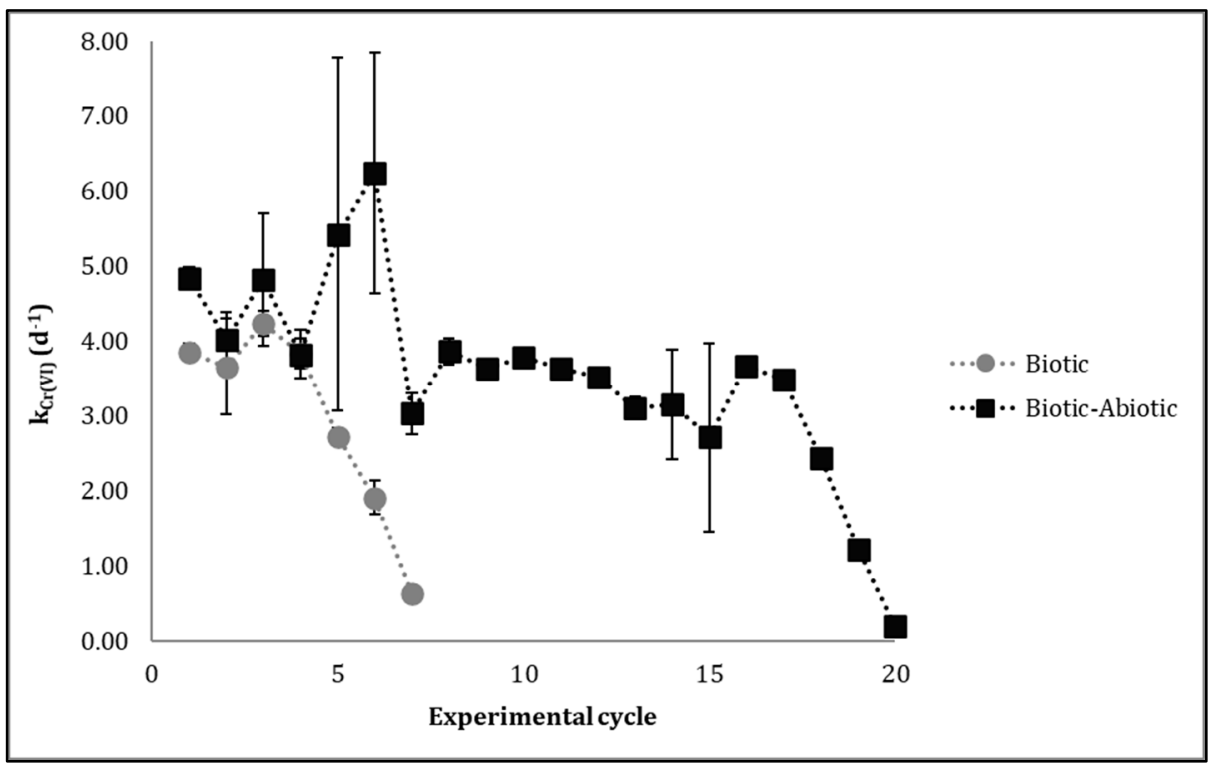

Figure 6. Time profiles of $\mathrm{Cr}(\mathrm{VI})$ reduction rates in the Biotic and Biotic-Abiotic experiments for each experimental cycle (error bars are equal to standard deviation).

It is also worth noting that, as shown in Tables 5 and 6, during the biotic-abiotic experiment soil permeability was reduced by $92.1 \pm 3.1 \%$, while in the biotic experiment only by $54.1 \pm 13.0 \%$. This difference in soil permeability reduction is attributed to physical clogging due to the addition of ferrous sulfate and the creation of insoluble $\mathrm{Cr}(\mathrm{III})$.

The presence of $\mathrm{Cr}(\mathrm{III})$ in the soil of both columns was confirmed with Graphite furnace atomic absorption analysis when the experiments were terminated. Total $\mathrm{Cr}$ concentration was $2339 \pm 28 \mathrm{mg} / \mathrm{kg}$, which is close to the expected concentration, if we take into consideration the initial concentration of $\mathrm{Cr}$ was $2195 \mathrm{mg} / \mathrm{kg}$ and the amount of $\mathrm{Cr}(\mathrm{VI})$ removal.

\section{Conclusions}

The aim of this study was to examine the potential microbial $\mathrm{Cr}(\mathrm{VI})$ reduction to $\mathrm{Cr}(\mathrm{III})$ by biostimulation through the addition of two carbon sources (molasses and EVO) and to assess the potential of $\mathrm{Cr}(\mathrm{VI})$ reduction by a coupled biotic-abiotic pathway. $\mathrm{Cr}(\mathrm{VI})$ conversion rates and total $\mathrm{Cr}(\mathrm{VI})$ removal were investigated in soil columns under anaerobic 
conditions. The findings from the experiments could be summarized into the following conclusions.

- Natural soil attenuation in the Cr-contaminated aquifer studied was low and was significantly exceeded by the amount of $\mathrm{Cr}(\mathrm{VI})$ in contaminated groundwater;

- Addition of organic electron donors can increase $\mathrm{Cr}(\mathrm{VI})$ reduction rate up to 20 times in comparison to the natural soil capacity rates;

- Ferrous iron has low mobility in soil and groundwater with a pH close to 8 and is rendered passive quickly, leading to insignificant $\mathrm{Cr}(\mathrm{VI})$ removal;

- Combined biotic-abiotic $\mathrm{Cr}(\mathrm{VI})$ removal exhibited a longer-life span in the remediation of $\mathrm{Cr}(\mathrm{VI})$-contaminated groundwater in comparison to biotic process.

Supplementary Materials: The following supporting information can be downloaded at: https: / /www.mdpi.com/article/10.3390/w14010089/s1, Figure S1: Time profile of $\mathrm{Cr}(\mathrm{VI})$ during the Control experiment in Column I.; Figure S2: Time profiles of $\mathrm{Cr}(\mathrm{VI})$ during the biotic experiment in Column I.; Figure S3: Time profiles of $\mathrm{Cr}(\mathrm{VI})$ during runs 1-12 of the biotic-abiotic experiment in Column I.; Figure S4: Time profiles of $\mathrm{Cr}(\mathrm{VI})$ during runs 13-20 of the biotic-abiotic experiment in Column I.; Figure S5: Time profile of $\mathrm{Cr}(\mathrm{VI})$ during the control experiment in Column II.; Figure S6: Time profiles of $\mathrm{Cr}(\mathrm{VI})$ during the biotic experiment in Column II.; Figure S7: Time profiles of $\mathrm{Cr}(\mathrm{VI})$ during runs 1-12 of the biotic-abiotic experiment in Column II.; Figure S8: Time profiles of $\mathrm{Cr}(\mathrm{VI})$ during runs 13-16 of the biotic-abiotic experiment in Column II.

Author Contributions: A.G.: conceptualization, methodology, experimental investigation, experimental work and data analysis, writing. D.M.: conceptualization, supervision, data analyses, writing一review \& editing. C.N.: conceptualization, supervision, writing—review \& editing. P.A. and A.V.: experimental work and data analyses. All authors have read and agreed to the published version of the manuscript.

Funding: This research received no external funding.

Institutional Review Board Statement: Not applicable.

Informed Consent Statement: Not applicable.

Data Availability Statement: The data presented in this study are available within the article and supplementary material. For any additional data the corresponding authors may be contacted.

Acknowledgments: This research is co-financed by Greece and the European Union (European Social Fund-ESF) through the Operational Programme «Human Resources Development, Education and Lifelong Learning» in the context of the project "Strengthening Human Resources Research Potential via Doctorate Research" (MIS-5000432), implemented by the State Scholarships Foundation (IK $\curlyvee$ ).

Conflicts of Interest: The authors declare no conflict of interest.

\section{References}

1. Kazakis, N.; Kantiranis, N.; Kalaitzidou, K.; Kaprara, E.; Mitrakas, M.; Frei, R.; Vargemezis, G.; Vogiatzis, D.; Zouboulis, A.; Filippidis, A. Environmentally available hexavalent chromium in soils and sediments impacted by dispersed fly ash in Sarigkiol basin (Northern Greece). Environ. Pollut. 2018, 235, 632-641. [CrossRef] [PubMed]

2. Perraki, M.; Vasileiou, E.; Bartzas, G. Tracing the origin of chromium in groundwater: Current and new perspectives. Curr. Opin. Environ. Sci. Health 2021, 22, 100267. [CrossRef]

3. Dhal, B.; Thatoi, H.N.; Das, N.N.; Pandey, B.D. Chemical and microbial remediation of hexavalent chromium from contaminated soil and mining/metallurgical solid waste: A review. J. Hazard. Mater. 2013, 250, 272-291. [CrossRef]

4. Jones, A.S.; Marini, J.; Solo-Gabriele, H.M.; Robey, N.M.; Townsend, T.G. Arsenic, copper, and chromium from treated wood products in the U.S. disposal sector. Waste Manag. 2019, 87, 731-740. [CrossRef]

5. Yang, Y.; Ma, H.; Chen, X.; Zhu, C.; Li, X. Effect of incineration temperature on chromium speciation in real chromium-rich tannery sludge under air atmosphere. Environ. Res. 2020, 183, 109159. [CrossRef] [PubMed]

6. Tumolo, M.; Ancona, V.; De Paola, D.; Losacco, D.; Campanale, C.; Massarelli, C.; Uricchio, V.F. Chromium Pollution in European Water, Sources, Health Risk, and Remediation Strategies: An Overview. Int. J. Environ. Res. Public Health 2020, 17, 5438. [CrossRef] [PubMed]

7. Wei, M.; Li, W.; Tang, J.; Barnie, S.; Zhang, J.; Chen, H. New insight into mechanism of Cr(VI) migration and transformation in typical soils of chromite ore processing residue (COPR) contaminated sites. Environ. Earth Sci. 2021, 80, 673. [CrossRef] 
8. Racek, J.; Trefil, L.; Rajdl, D.; Mudrová, V.; Hunter, D.; Senft, V. Influence of Chromium-Enriched Yeast on Blood Glucose and Insulin Variables, Blood Lipids, and Markers of Oxidative Stress in Subjects with Type 2 Diabetes Mellitus. Biol. Trace Elem. Res. 2006, 109, 215-230. [CrossRef]

9. Nussbaumerova, B.; Rosolova, H.; Krizek, M.; Sefrna, F.; Racek, J.; Müller, L.; Sindberg, C. Chromium Supplementation Reduces Resting Heart Rate in Patients with Metabolic Syndrome and Impaired Glucose Tolerance. Biol. Trace Elem. Res. 2018, 183, 192-199. [CrossRef]

10. Vithanage, M.; Kumarathilaka, P.; Oze, C.; Karunatilake, S.; Seneviratne, M.; Hseu, Z.Y.; Gunarathne, V.; Dassanayake, M.; Ok, Y.S.; Rinklebe, J. Occurrence and cycling of trace elements in ultramafic soils and their impacts on human health: A critical review. Environ. Int. 2019, 131, 104974. [CrossRef]

11. Sheikhhossein, F.; Amini, M.R.; Shahinfar, H.; Djafari, F.; Safabakhsh, M.; Shab-Bidar, S. Effects of chromium supplementation on inflammatory biomarkers: A systematic review and dose-response meta-analysis of randomized controlled trials. Eur. J. Integr. Med. 2020, 37, 101147. [CrossRef]

12. Wang, Y.; Su, H.; Gu, Y.; Song, X.; Zhao, J. Carcinogenicity of chromium and chemoprevention: A brief update. OncoTargets Ther. 2017, 10, 4065-4079. [CrossRef] [PubMed]

13. Di Palma, L.; Gueye, M.T.; Petrucci, E. Hexavalent chromium reduction in contaminated soil: A comparison between ferrous sulphate and nanoscale zero-valent iron. J. Hazard. Mater. 2015, 281, 70-76. [CrossRef]

14. Mishra, S.; Bharagava, R.N. Toxic and genotoxic effects of hexavalent chromium in environment and its bioremediation strategies. J. Environ. Sci. Health Part C Environ. Carcinog. Ecotoxicol. Rev. 2016, 34, 1-32. [CrossRef]

15. EPA. National Primary Drinking Water Regulations; EPA 816-F-09-004; EPA: Washington, DC, USA, 2009.

16. WHO. WHO Guidelines for Drinking Water, 3rd ed.; World Health Organization: Geneva, Switzerland, 2004.

17. Oze, C.; Bird, D.K.; Fendorf, S. Genesis of hexavalent chromium from natural sources in soil and groundwater. Proc. Natl. Acad. Sci. USA 2007, 104, 6544-6549. [CrossRef] [PubMed]

18. Economou-Eliopoulos, M.; Megremi, I.; Vasilatos, C. Factors controlling the heterogeneous distribution of Cr(VI) in soil, plants and groundwater: Evidence from the Assopos basin, Greece. Geochemistry 2011, 71, 39-52. [CrossRef]

19. Eliopoulos, I.P.D.; Eliopoulos, G.D.; Economou-Eliopoulos, M. The cr(Vi) stability in contaminated coastal groundwater: Salinity as a driving force. Minerals 2021, 11, 160. [CrossRef]

20. Paternoster, M.; Rizzo, G.; Sinisi, R.; Vilardi, G.; Di Palma, L.; Mongelli, G. Natural Hexavalent Chromium in the Pollino Massif Groundwater (Southern Apennines, Italy): Occurrence, Geochemistry and Preliminary Remediation Tests by Means of Innovative Adsorbent Nanomaterials. Bull. Environ. Contam. Toxicol. 2021, 106, 421-427. [CrossRef]

21. Dermatas, D.; Panagiotakis, I.; Mpouras, T.; Tettas, K. The Origin of Hexavalent Chromium as a Critical Parameter for Remediation of Contaminated Aquifers. Bull. Environ. Contam. Toxicol. 2017, 98, 331-337. [CrossRef]

22. Barrera-Díaz, C.E.; Lugo-Lugo, V.; Bilyeu, B. A review of chemical, electrochemical and biological methods for aqueous Cr(VI) reduction. J. Hazard. Mater. 2012, 223, 1-12. [CrossRef] [PubMed]

23. Mishra, S.; Chowdhary, P.; Bharagava, R.N. Conventional methods for the removal of industrial pollutants, their merits and demerits. In Emerging and Eco-Friendly Approaches for Waste Management; Springer: Singapore, 2018; pp. 1-31. [CrossRef]

24. Jobby, R.; Jha, P.; Yadav, A.K.; Desai, N. Biosorption and biotransformation of hexavalent chromium [Cr(VI)]: A comprehensive review. Chemosphere 2018, 207, 255-266. [CrossRef] [PubMed]

25. Elahi, A.; Rehman, A. Comparative behavior of two gram positive $\mathrm{Cr} 6+$ resistant bacterial strains Bacillus aerius S1 and Brevibacterium iodinum S2 under hexavalent chromium stress. Biotechnol. Rep. 2019, 21, e00307. [CrossRef] [PubMed]

26. Pushkar, B.; Sevak, P.; Parab, S.; Nilkanth, N. Chromium pollution and its bioremediation mechanisms in bacteria: A review. J. Environ. Manag. 2021, 287, 112279. [CrossRef] [PubMed]

27. Song, X.; Wang, Q.; Jin, P.; Chen, X.; Tang, S.; Wei, C.; Li, K.; Ding, X.; Tang, Z.; Fu, H. Enhanced biostimulation coupled with a dynamic groundwater recirculation system for $\mathrm{Cr}(\mathrm{VI})$ removal from groundwater: A field-scale study. Sci. Total Environ. 2021, 772, 145495. [CrossRef] [PubMed]

28. Das, S.; Chandra Behera, B.; Mohapatra, R.K.; Pradhan, B.; Sudarshan, M.; Chakraborty, A.; Thatoi, H. Reduction of hexavalent chromium by Exiguobacterium mexicanum isolated from chromite mines soil. Chemosphere 2021, 282, 131135. [CrossRef] [PubMed]

29. Park, C.H.; Keyhan, M.; Wielinga, B.; Fendorf, S.; Matin, A. Purification to homogeneity and characterization of a novel Pseudomonas putida chromate reductase. Appl. Environ. Microbiol. 2000, 66, 1788-1795. [CrossRef]

30. Opperman, D.J.; Piater, L.A.; Van Heerden, E. A novel chromate reductase from Thermus scotoductus SA-01 related to old yellow enzyme. J. Bacteriol. 2008, 190, 3076-3082. [CrossRef]

31. Ma, Y.; Zhong, H.; He, Z. Cr(VI) reductase activity locates in the cytoplasm of Aeribacillus pallidus BK1, a novel Cr(VI)-reducing thermophile isolated from Tengchong geothermal region, China. Chem. Eng. J. 2019, 371, 524-534. [CrossRef]

32. Pei, Y.; Tao, C.; Ling, Z.; Yu, Z.; Ji, J.; Khan, A.; Mamtimin, T.; Liu, P.; Li, X. Exploring novel Cr(VI) remediation genes for $\mathrm{Cr}(\mathrm{VI})$-contaminated industrial wastewater treatment by comparative metatranscriptomics and metagenomics. Sci. Total Environ. 2020, 742, 140435. [CrossRef]

33. Wielinga, B.; Mizuba, M.M.; Hansel, C.M.; Fendorf, S. Iron promoted reduction of chromate by dissimilatory iron-reducing bacteria. Environ. Sci. Technol. 2001, 35, 522-527. [CrossRef] 
34. Fernández, P.M.; Viñarta, S.C.; Bernal, A.R.; Cruz, E.L.; Figueroa, L.I.C. Bioremediation strategies for chromium removal: Current research, scale-up approach and future perspectives. Chemosphere 2018, 208, 139-148. [CrossRef] [PubMed]

35. Bishop, M.E.; Dong, H.; Glasser, P.; Briggs, B.R.; Pentrak, M.; Stucki, J.W.; Boyanov, M.I.; Kemner, K.M.; Kovarik, L. Reactivity of redox cycled Fe-bearing subsurface sediments towards hexavalent chromium reduction. Geochim. Cosmochim. Acta 2019, 252, 88-106. [CrossRef]

36. Fendorf, S.; Wielinga, B.W.; Hansel, C.M. Chromium Transformations in Natural Environments: The Role of Biological and Abiological Processes in Chromium(VI) Reduction. Int. Geol. Rev. 2000, 42, 691-701. [CrossRef]

37. Nevin, K.P.; Lovley, D.R. Mechanisms for Fe(III) oxide reduction in sedimentary environments. Geomicrobiol. J. 2002, 19, 141-159. [CrossRef]

38. Arias, Y.M.; Tebo, B.M. Cr(VI) reduction by sulfidogenic and nonsulfidogenic microbial consortia. Appl. Environ. Microbiol. 2003, 69, 1847-1853. [CrossRef] [PubMed]

39. Jiang, K.; Zhang, J.; Deng, Z.; Barnie, S.; Chang, J.; Zou, Y.; Guan, X.; Liu, F.; Chen, H. Natural attenuation mechanism of hexavalent chromium in a wetland: Zoning characteristics of abiotic and biotic effects. Environ. Pollut. 2021, 287, 117639. [CrossRef]

40. Michailides, M.K.; Tekerlekopoulou, A.G.; Akratos, C.S.; Coles, S.; Pavlou, S.; Vayenas, D.V. Molasses as an efficient low-cost carbon source for biological Cr(VI) removal. J. Hazard. Mater. 2015, 281, 95-105. [CrossRef]

41. Ancona, V.; Campanale, C.; Tumolo, M.; De Paola, D.; Ardito, C.; Volpe, A.; Uricchio, V.F. Enhancement of chromium (VI) reduction in microcosms amended with lactate or yeast extract: A laboratory-scale study. Int. J. Environ. Res. Public Health 2020, 17, 704. [CrossRef]

42. Mortensen, A.; Larsen, J.C. Risk assessment of sweeteners used as food additives. In Sweeteners: Nutritional Aspects, Applications, and Production Technology; CRC Press: Boca Raton, FL, USA, 2012; pp. 419-435.

43. Chen, Z.F.; Zhao, Y.S.; Zhang, J.W.; Bai, J. Mechanism and Kinetics of Hexavalent Chromium Chemical Reduction with Sugarcane Molasses. Water. Air. Soil Pollut. 2015, 226, 363. [CrossRef]

44. Sun, Y.; Lan, J.; Du, Y.; Li, Z.; Liao, X.; Du, D.; Ye, H.; Zhang, T.C.; Chen, S. Efficient removal of heavy metals by synergistic actions of microorganisms and waste molasses. Bioresour. Technol. 2020, 302, 122797. [CrossRef] [PubMed]

45. Jeyasingh, J.; Philip, L. Bioremediation of chromium contaminated soil: Optimization of operating parameters under laboratory conditions. J. Hazard. Mater. 2005, 118, 113-120. [CrossRef]

46. Tokunaga, T.K.; Wan, J.; Firestone, M.K.; Hazen, T.C.; Olson, K.R.; Herman, D.J.; Sutton, S.R.; Lanzirotti, A. Bioremediation and Biodegradation In Situ Reduction of Chromium(VI) in Heavily Contaminated Soils through Organic Carbon Amendment. J. Environ. Qual. 2003, 32, 1641-1649. [CrossRef] [PubMed]

47. Tang, G.; Watson, D.B.; Wu, W.M.; Schadt, C.W.; Parker, J.C.; Brooks, S.C. U(VI) bioreduction with emulsified vegetable oil as the electron donor -model application to a field test. Environ. Sci. Technol. 2013, 47, 3218-3225. [CrossRef]

48. Borden, R.C. Effective distribution of emulsified edible oil for enhanced anaerobic bioremediation. J. Contam. Hydrol. 2007, 94, 1-12. [CrossRef] [PubMed]

49. Dong, J.; Yu, J.; Bao, Q. Simulated reactive zone with emulsified vegetable oil for the long-term remediation of $\mathrm{Cr}(\mathrm{VI})$-contaminated aquifer: Dynamic evolution of geological parameters and groundwater microbial community. Environ. Sci. Pollut. Res. 2018, 25, 34392-34402. [CrossRef] [PubMed]

50. Wen, C.; Sheng, H.; Ren, L.; Dong, Y.; Dong, J. Study on the removal of hexavalent chromium from contaminated groundwater using emulsified vegetable oil. Process Saf. Environ. Prot. 2017, 109, 599-608. [CrossRef]

51. Somasundaram, V.; Philip, L.; Bhallamudi, S.M. Laboratory scale column studies on transport and biotransformation of Cr(VI) through porous media in presence of CRB, SRB and IRB. Chem. Eng. J. 2011, 171, 572-581. [CrossRef]

52. Lu, J.; Zhang, B.; He, C.; Borthwick, A.G.L. The role of natural Fe(II)-bearing minerals in chemoautotrophic chromium (VI) bio-reduction in groundwater. J. Hazard. Mater. 2020, 389, 121911. [CrossRef] [PubMed]

53. Stroo, H.F.; Leeson, A.; Ward, C.H. Bioaugmentation for Groundwater Remediation; Springer: New York, NY, USA, 2012.

54. Hach LCS313 Chromium Trace Method. Available online: https://gr.hach.com/iii-vi-0-005-0-25-mg-1-cr/product-downloads? $\mathrm{id}=26370285876 \&$ callback $=q \mathrm{~s}$ (accessed on 26 October 2021).

55. USEPA Method 7196A for Chromium Hexavalent (colorimetric). USEPA Method 7196A 1992, 1-6. Available online: https: //www.epa.gov/sites/default/files/2015-12/documents/7196a.pdf (accessed on 26 October 2021).

56. Baird, R.; Bridgewater, L. 5220 CHEMICAL OXYGEN DEMAND (COD). In Standard Methods for the Examination of Water and Wastewater, 23rd ed.; American Public Health Association: Washington, DC, USA, 2017.

57. Baird, R.; Bridgewater, L. 3500-Fe IRON. In Standard Methods for the Examination of Water and Wastewater, 23rd ed.; American Public Health Association: Washington, DC, USA, 2017.

58. ASTM International. Standard Test Method for Permeability of Granular Soils (Constant Head). In Annual Book of ASTM Standards; ASTM International: West Conshohocken, PA, USA, 2019; pp. 1-6.

59. Mamais, D.; Noutsopoulos, C.; Kavallari, I.; Nyktari, E.; Kaldis, A.; Panousi, E.; Nikitopoulos, G.; Antoniou, K.; Nasioka, M. Biological groundwater treatment for chromium removal at low hexavalent chromium concentrations. Chemosphere 2016, 152, 238-244. [CrossRef] 
60. Panousi, E.; Mamais, D.; Noutsopoulos, C.; Antoniou, K.; Koutoula, K.; Mastrantoni, S.; Koutsogiannis, C.; Gkioni, A. Biological treatment of groundwater with a high hexavalent chromium content under anaerobic and anoxic conditions. J. Chem. Technol. Biotechnol. 2016, 91, 1681-1687. [CrossRef]

61. Amann, R.I.; Krumholz, L.; Stahl, D.A. Fluorescent-oligonucleotide probing of whole cells for determinative, phylogenetic, and environmental studies in microbiology. J. Bacteriol. 1990, 172, 762-770. [CrossRef] [PubMed]

62. Stahl, D.A.; Amann, R. Development and application of nucleic acid probes in bacterial systematics. In Nucleic Acid Techniques in Bacterial Systematics, 1st ed.; Stackebrandt, E., Goodfellow, M., Eds.; Wiley \& Sons Ltd.: Chichester, UK, 1991; pp. 205-248.

63. Raskin, L.; Stromley, J.M.; Rittmann, B.E.; Stahl, D.A. Group-specific 16S rRNA hybridization probes to describe natural communities of methanogens. Appl. Environ. Microbiol. 1994, 60, 1232-1240. [CrossRef] [PubMed]

64. Manz, W.; Amann, R.; Ludwig, W.; Wagner, M.; Schleifer, K. Phylogenetic oligodeoxynucleotide probes for the major subclasses of proteobacteria: Problems and solutions. Syst. Appl Microbiol. 1992, 15, 593-600. [CrossRef]

65. Loy, A.; Lehner, A.; Lee, N.; Adamczyk, J.; Meier, H.; Ernst, J.; Schleifer, K.H.; Wagner, M. Oligonucleotide microarray for $16 \mathrm{~S}$ rRNA gene-based detection of all recognized lineages of sulfate-reducing prokaryotes in the environment. Appl. Environ. Microbiol. 2002, 68, 5064-5081. [CrossRef] [PubMed]

66. Lücker, S.; Steger, D.; Kjeldsen, K.U.; MacGregor, B.J.; Wagner, M.; Loy, A. Improved 16S rRNA-targeted probe set for analysis of sulfate-reducing bacteria by fluorescence in situ hybridization. J. Microbiol. Methods 2007, 69, 523-528. [CrossRef]

67. Küsel, K.; Pinkart, H.C.; Drake, H.L.; Devereux, R. Acetogenic and sulfate-reducing bacteria inhabiting the rhizoplane and deep cortex cells of the sea grass Halodule wrightii. Appl. Environ. Microbiol. 1999, 65, 5117-5123. [CrossRef]

68. Holmes, D.E.; Giloteaux, L.; Barlett, M.; Chavan, M.A.; Smith, J.A.; Williams, K.H.; Wilkins, M.; Long, P.; Lovley, D.R. Molecular analysis of the In situ growth rates of subsurface geobacter species. Appl. Environ. Microbiol. 2013, 79, 1646-1653. [CrossRef]

69. Nielsen, J.L.; Juretschko, S.; Wagner, M.; Nielsen, P.H. Abundance and phylogenetic affiliation of iron reducers in activated sludge as assessed by fluorescence in situ hybridization and microautoradiography. Appl. Environ. Microbiol. 2002, 68, 4629-4636. [CrossRef]

70. Guo, J.; Lian, J.; Xu, Z.; Xi, Z.; Yang, J.; Jefferson, W.; Liu, C.; Li, Z.; Yue, L. Reduction of Cr(VI) by Escherichia coli BL21 in the presence of redox mediators. Bioresour. Technol. 2012, 123, 713-716. [CrossRef]

71. Grady, C.P.L.; Daigger, G.T.; Love, N.G.; Filipe, C.D.M. Biological Wastewater Treatment, 3rd ed.; CRC Press: Boca Raton, FL, USA, 2011.

72. Shashidhar, T.; Philip, L.; Bhallamudi, S.M. Bench-scale column experiments to study the containment of Cr(VI) in confined aquifers by bio-transformation. J. Hazard. Mater. 2006, 131, 200-209. [CrossRef]

73. Krishna, K.R.; Philip, L. Bioremediation of Cr(VI) in contaminated soils. J. Hazard. Mater. 2005, 121, 109-117. [CrossRef] [PubMed]

74. Génin, J.M.R.; Refait, P.H.; Abdelmoula, M. Green rusts and their relationship to iron corrosion: A key role in microbially influenced corrosion. Hyperfine Interact. 2002, 139, 119-131. [CrossRef]

75. Ona-Nguema, G.; Abdelmoula, M.; Jorand, F.; Benali, O.; Géhin, A.; Block, J.C.; Génin, J.M.R. Iron(II,III) hydroxycarbonate green rust formation and stabilization from lepidocrocite bioreduction. Environ. Sci. Technol. 2002, 36, 16-20. [CrossRef] [PubMed]

76. Zhong, J.; Yin, W.; Li, Y.; Li, P.; Wu, J.; Jiang, G.; Gu, J.; Liang, H. Column study of enhanced Cr(VI) removal and longevity by coupled abiotic and biotic processes using Fe0 and mixed anaerobic culture. Water Res. 2017, 122, 536-544. [CrossRef] 